\title{
CLASSIFICATION OF CRIMINAL GROUPS
}

\author{
Natalia Romanova, Saratov State University, romanovanm@info.sgu.ru
}

\begin{abstract}
New types of criminal groups are emerging in modern society. These types have their special criminal subculture. The research objective is to develop new parameters of classification of modern criminal groups, create a new typology of criminal groups and identify some features of their subculture. Research methodology is based on the system approach that includes using the method of analysis of documentary sources (materials of a criminal case), method of conversations with the members of the criminal group, method of testing the members of the criminal group and method of observation. As a result of the conducted research, we have created a new classification of criminal groups. The first type is a lawful group in its form and criminal according to its content (i.e., its target is criminal enrichment). The second type is a criminal organization which is run by so-called "white-collars" that "remain in the shadow". The third type is traditional criminal groups. The fourth type is the criminal group, which openly demonstrates its criminal activity.
\end{abstract}

UDC Numbers: 316.6, 343.953, DOI: 10.12955/cbup.2013.25

Keywords: criminal, typology, subculture, groups

\section{Introduction}

Transformation of all the aspects of socio-economic and political life of Russia in the early 90's of the last century produced not only positive (freedom, democracy, market economy), but negative impact as well. The most important one of them is connected with rapid growth of criminal behavior, including group crimes.

Growth in the number of crimes is accompanied by active penetration, dissemination and implementation of the criminal subculture, criminal lifestyle, and criminal valuesin the social structure of the society. Most of the activities of the criminal groups remain unsolved. It is typical for our society. Albanase, J.S (2003) found out that phenomenon like this is characteristic for many countries. In this article, we have described types of criminal groups and features of their subculture.

\section{Literature review}

Mikhailov (2009) believes that the criminalization of Russian society at the present time is the most important and topical issue.

Korelkin \& Mikhailov (2012), Pirozhkov (2012), Sochivko \& Polyanin (2009) showed that in modern Russian society reproduction of criminal behavior occurs by combining the values of the criminal subculture and traditional culture. With wide distribution of rules of criminal subculture, decreases prosocial values'impact on young people and adolescents. Kudryavtsev (2002) wrote that it is 
difficult to keep within the law-abiding behavior mature persons. Cherkasova (2009) found out that the criminal subculture gradually introduced into the structure of the business and industrial relations. It becomes part of the communication of people.

Current classification of criminal groups in the Russian national criminology and criminal psychology are generally structured by the parameters of the level of criminalization and organization. Enikeev (2006) classified in accordance with the parameters of the following types of criminal communities: pre-criminal groups, simple criminal groups, organized criminal groups, and criminal organizations.

In addition, scientific literature has a classification of criminal groups based on parameters of their focus and scale of their activity: common criminal groups and organized criminal groups (criminal organizations).

\section{Data and methodology}

Crime committed by a group means its orientation towards criminal values and criminal subculture. However, modern subculture is a multidimensional phenomenon, which can disintegrate into its various subtypes. On the one hand it can be a traditional criminal subculture, based on the norms of prison culture. On the other hand, it is a combination of criminal and individualistic values, the culture of competition.

Common criminal groups are characterized by the commission of street and domestic crimes, such as theft, fraud, robbery, brigandage. The action vector of common criminal groups can be characterized as action against the society. They act illegitimately, in the underhand way, secretly. Members of such groups are characterized by antisocial behavior, acceptance of violence, adherence to criminal values and norms, consideration of the criminal image as something attractive for themselves, focus on shortterm gains, short-term pleasure (entertainment, booze).

Crimes committed by such criminal groups are subjected to concealment, masking and destruction of traces of the crime. As a rule, traditional common criminal groups are oriented towards values of hedonistic street culture and have no links with corruption.

Dolgova (2007) found out that vector of action of the organized criminal groups (criminal organizations) is aimed within (inside) the social "body", and orientated towards the inclusion into the society's social life.

Within the framework of criminal organizations there often happens some kind of "tangle" between legal and criminal types of activities.

The tactics of such groups is parasitism on the mechanisms of functioning of social institutions of the society, social mimicry, and masking. Due to this, the retracting of unstable conformal personality into criminal activity occurs gradually, sometimes unnoticeably for him/her.

Subculture of organized criminal groups is inherently oriented towards the rules of the criminal world and the criminal subculture, including orientation towards receiving extra profits by any means, cynicism and amorality. Additional incentive is a focus on the culture of competition, achievement of material success at any cost.

Criminals belonging to criminal organizations are a new type of offender. Many of them have a high level of education, erudition, socialized behavior, they look presentable. They are characterized by a 
high desire for wealth and prosperity. Organized crime groups are willing to legalize their activities by establishing official firms and companies.

Intensive changes observed in modern society are actively used among ordinary members of criminal groups and among members of organized crime. This usage relates to adaptation of social conditions, events and circumstances (planning "blunders", "gaps" of legislation, "weak points" of the social system, back-log of needs and expectations of people, demand for social practices) for their own purposes. This tendency is especially typical of organized crime. It uses not only failures in social functioning, but also deliberately creates conditions for expanding of the areas of self-actualization of the criminal group.

Thus, as it follows from the analysis given above, for modern criminal groups it is typical to have: secret or open mode of operation, involvement or absence of government agencies that perform the function of protection and lobbying of interests of the criminal organization into the group.

Material for research was received from the qualitative analysis of data of forensic psychology with the use of the followed methods: 1.method of analysis of documentary sources (materials of a criminal case); 2.method of conversations with members of the criminal group; 3.method of testing the members of the criminal group; 4.method of observation. Methodology of research is systems approach.

\section{Results and discussion}

Based on the analysis of the materials, it is possible to construct the classification of modern criminal groups with the following structuring features:

a) mode of operation (secret - open),

b) factor of power and administrative support (presence - absence).

It is possible to identify the parameters on the basis of these features: "legitimacy - lack of legitimacy", "presence of corruption - no links with corruption". Graphically this classification can be shown as follows:

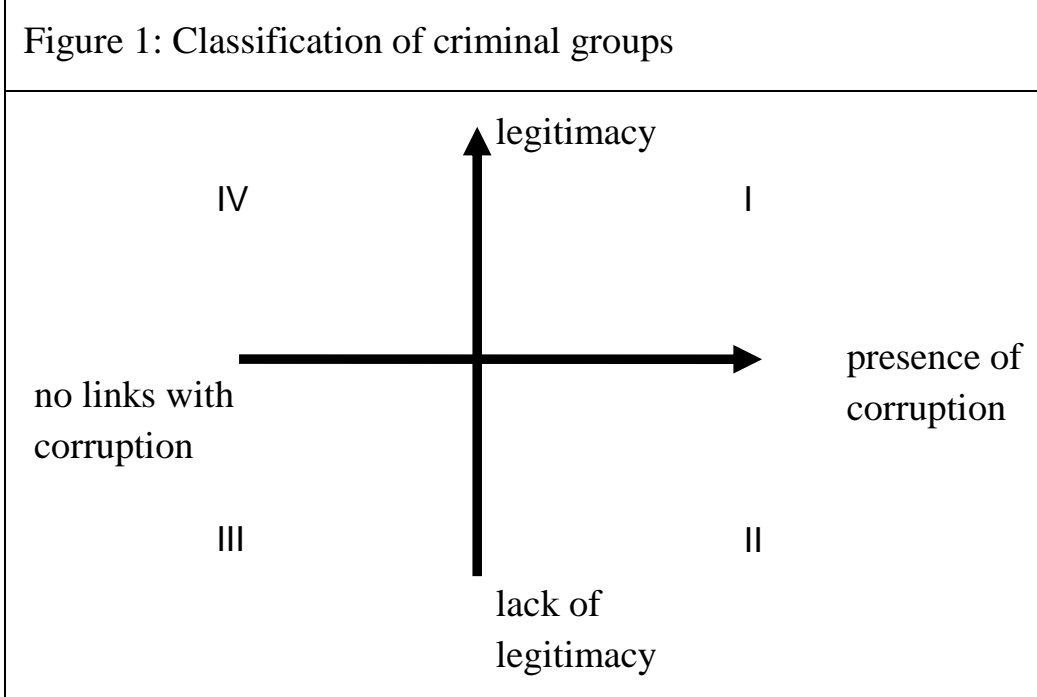

Source: Author 
Then there is open criminal organization presented in quadrant I: legitimate, lawful in form (commercial firm or organization) and criminal according to its content (target - criminal enrichment). This type of organizations is run by criminal bosses. A group acts "undercover" and its interests, as a rule, are actively lobbied from the "top". Herewith its activity is effective: corrupt officials and highranking security officials render such organizations with all-round assistance, support and protection. As a rule such groups are created in order to simulate commercial activities (pseudo entrepreneurship).

There is a criminal organization in quadrant II which is run by so-called "white-collars" that "remain in the shadow". As a rule, the rank-and-file members of such criminal organization do not know their leaders who hold high positions in the power-holding structures, determining and directing this criminal organization`s activity. The group preserves conspiracy, controls the information leaks and severely punishes misbehaving members. Typically, such group is engaged in illegal activities that bring in high illegal income (drug and weapon trade, gambling industry etc.). Traditional criminal group is presented in the quadrant III. This group acts secretly and commits periodic criminal actions in the form of individual crimes (plunder, robbery, murder, theft).

Such groups are characterized by alcohol and drug abuse. The group members keep group secrets and hide the existence of a group from people around. They use criminal jargon, nicknames and tattoos as means of communication. Subculture that is asocial and primitive on the surface is the one that dominates there. It is the basic criminalizing mechanism of such groups' existence. Behavior standards of its members contradict the ones, which are accepted in a civilized society (nicknames, slang, cruelty towards the weak, and cynicism).

Quadrant IV describes the criminal group, which openly demonstrates criminal activity - "at their own risk" (sly frauds, calculated to deceive gullible citizens and sluggishness of law-enforcement agencies). Such groups act promptly, in a non standard way, saucily. They count on luck and criminal professionalism.

The culture of all of criminal groups described above contains antisocial criminal subculture, each having a specific subculture and organizational culture. For instance, a legitimate criminal subculture group having corruption links is characterized by active use of knowledge, taken both from the fields of practical and scientific psychology: involving pro-social symbolism and high etiquette standards, including behavior available for observation, speech etiquette, requirements for exterior office design, employees' dress code etc.

As a result, a peculiar mixture of antisocial criminal subculture and organizational culture takes place, in which the emphasis is made on the outer signs (imitation of external signs of legitimate official social group). External presentation is designed for outside observers - potential clients and customers. However, asocial and antisocial behaviors are the internal content of its organizational culture and subculture. The purpose of the group is the criminal one.

Gradually but quickly enough (in the course of weeks' or months' time) the internal integration of the group members takes place: they know how to act, how to interact and cooperate with each other. Such groups have a high level of adaptability to the social and cultural environment.

Internal acceptance of organizational culture and subculture of such a group results in organization`s employees personality disorders through gradual internal integration to identification with the criminal group. Such groups use the latest progress and achievements of organizational psychology, which contributes to the success of the criminal group. 
Some employees recruited by the criminal group demonstrate high involvement in its activity, that is a result of effective organizational culture that affects their personalities (pursuit of ambition, high performance, material and countenance support for members who distinguished themselves etc.).

The prevalence in our society of such kinds of criminal groups indicates the effectiveness of this type of formations. The reason being: lack of operational work of law enforcement agencies, their corruptness, low activism of citizens in terms of disclosure of such formations (passivity of legal consciousness).

Criminal groups having no corruption links (3 and 4) are simple and complex criminal groups. Such groups commit acquisitive crimes or acquisitive or violent crimes. Main features of subcultures of such groups are: they cultivate criminal ideas, beliefs and views. Criminals included into these groups are characterized by moral and legal nihilism, which makes it easier for them to commit crimes. Members of these groups are valued for such qualities as moral and physical strength, readiness to take risks, masculinity, and emotional stability. Members of such groups have limited access to legitimate way of achievement of social success and material prosperity.

\section{Conclusion}

Thereby, similarities between the described types of criminal groups are - the acceptance of criminal values (permissibility of breaking the law, acceptability of deception and manipulations, disregard of the interests of others). All the differences are connected with the content peculiarities of criminal subculture and its specific content. Research brings in a contribution to understanding of essence of the traditional and modern organized criminal groups.

\section{Acknowledgments}

This work was supported by the Russian Foundation for Humanities (grant number 13-06-00491).

\section{References}

Albanase, J. S. (2003). Tainstvennaia mafiia: organizovannaia prestupnost' [The mysterious mafia: organized crime]. In Sheley, J. F. (Eds.), Kriminologiia [Criminology], pp. 319-342. Saint Petersburg, Russia: Peter.

Cherkasova, Y. Y. (2009). Mif v kontekste tjuremnoj subkul'tury: avtoref. diss [Myth in the context of prison subculture]. (Doctoral dissertation). Rostov, Russia: Technological Institute of Southern Federal University.

Dolgova, A. I. (Ed.). (2007). Kriminologiya: uchebnik dlya vuzov [Criminology: University text book]. Moscow, Russia: Norma.

Enikeev, M. I. (2006). Juridicheskaja psihologija [Legal Psychology]. Saint Petersburg, Russia: Peter.

Korelkin, E. N. \& Mikhailov, A. P. (2012). Kriminal'naja subkul'tura: problemy jeskalacii v molodezhnom soznanii [Criminal subculture: the escalating youth in mind]. Herald SGUTiKD, 1 (19).

Kudryavtsev, V. N. (2002). Prestupnost' i nravy perehodnogo obshhestva [Crime and morals society in transition]. Moscow, Russia: Norma. PMCid:PMC123103 
Mikhailov, A. P. (2009). Sociokul'turnye faktory v jetiologii deviantnogo povedenija molodezhi [Socio-cultural factors in the etiology of deviant behavior of the youth]. Herald of Adygea State University, 2.

Pirozhkov, V. F. (2012). Kriminal'naya Psihologiya [Criminal Psychology]. Moscow, Russia: Os-89.

Sochivko, D.V. \& Polyanin, N.A. (2009). Kriminal'naja ideologemy sovremennyh molodezhnyh subkul'tur [Criminal ideologies of modern youth subcultures]. Prikladnaja juridicheskaja psihologija [Law applied psychology], 4. 